\title{
Investigation of the possibility of green bean production under unfavourable agro-ecological conditions in lysimeters
}

\author{
Lúcia SINKA, ${ }^{1 *}$ Mária TAKÁCS-HÁJOS, ${ }^{1}$ Krisztina CZELLÉR, ${ }^{2}$ \\ Géza TUBA, ${ }^{2}$ József ZSEMBELI ${ }^{2}$
}

\author{
${ }^{1}$ Faculty of Agricultural and Food Sciences and Environmental Management, Institute of \\ Horticultural Science, University of Debrecen, 138 Böszörményi St., H-4032 Debrecen, Hungary \\ *Corresponding author: sinkalucia@agr.unideb.hu \\ ${ }^{2}$ Research Institute of Karcag, Institutes for Agricultural Research and Educational Farm, \\ University of Debrecen, 166 Kisújszállási út, H-5300 Karcag, Hungary
}

Manuscript received May 15, 2019; revised May 30, 2019; Accepted June 22, 2019

\begin{abstract}
There are extended agricultural areas in the world that can be utilized only with irrigation for crop production. Improper irrigation may induce unfavourable processes in the soil (e.g. secondary salinization). To investigate this problem existing in Hungary as well, 12 simple drainage lysimeters - which are useful equipment for the investigation of the water and salt balance of the soil - were used in an irrigation experiment in the Research Institute of Karcag. The basic goal was to investigate the possibility of the production of a salt-sensitive crop (green bean) in areas with unfavourable agro-ecological conditions. 6 lysimeters were irrigated with deionized water, while the other 6 with saline water of $1,600 \mathrm{mg} / 1$ salt content. We also used a soil conditioner (Neosol) during the experiment. Analysing the effect of the irrigation quality on the plant height of green beans, it can be established that the plants irrigated with deionized water were averagely $5.3 \mathrm{~cm}$ taller than the plants irrigated with saline water. Similar tendencies were characteristic of the average biomass (deionized: 93.5, saline: $62.5 \mathrm{~g}$ ), the average root mass (deionized: $9.5 \mathrm{~g}$, saline: $8.2 \mathrm{~g}$ ), the number of pods (deionized: 17.1, saline: 11.9), and the pod yield (deionized: $137.9 \mathrm{~g}$, saline: $85.9 \mathrm{~g}$ ) values. However, all these values can be improved by soil conditioning combined with the optimization of irrigation.
\end{abstract}

Keywords: irrigation, secondary salinization, vegetable production 


\section{Introduction}

Nowadays, the presence of weather extremes is becoming more and more frequent. Climate is the primary determinant of agricultural productivity; therefore, understanding and estimating the effects of climate change on food production and supply are the responsibility of humans [1].

For cropping systems, one of the most important tasks to maintain the quality of producing is perhaps changing varieties/species to those which can adapt to changes more efficiently (e.g. better resistance to heat shock and drought). Furthermore, instead of using "water-waste" technologies, conserving soil moisture could result in a more productive agricultural system in spite of the unfavourable agro-ecological conditions [2].

In Hungary, especially on the Great Plain (which is the central area of crop production in the country), climate changes affect agricultural production negatively as well. Unfortunately, drought is more and more frequent in the summer period, and thus irrigation is essential for the vegetables with high water demand. Beyond the unfavourable ecological conditions, the frequency of weather extremes (extra-dry or -wet periods) is higher compared to the other regions of Hungary.

Irrigation makes agricultural production safer and more intensive, though it is well known that it can also have negative effects on the soil. Improper irrigation practice can cause soil degradation such as decrease in fertility. This is an extended problem in Great Cumania (a subregion in Hungary in the Trans-Tisza region) as half of its territory is covered primarily by salt-affected soils, while the other half is covered by better soils (chernozems); however, these soils are susceptible to secondary salinization induced by irrigation. According to Szabolcs et al. [6, 7], secondary salinization has two reasons: salt accumulation due to the application of saline water or the rise of the salty groundwater transporting salts up to the upper soil layers.

Our research work is based on a previous review which focused on the importance of irrigation in the droughty periods; however, the quality of water used for irrigation in the hobby gardens around Karcag can cause secondary salinization by the application of inappropriate irrigation techniques.

On the basis of our preliminary survey, it could be concluded that the water quality of the aquifers (well waters) is not suitable for irrigation due to their high salt content.

If we take all these conditions given, the question arises as to whether sustainable plant production can be carried out in the region. In order to answer this question in a scientifically established way, an experiment was set up with a salt-sensitive vegetable (green bean) at the lysimeter station of the Research Institute of Karcag (RIK), University of Debrecen. Lysimeters are suitable tools 
to investigate the possibility of green bean production under unfavourable agroecological conditions in a well-defined environment. Practically, we simulated the typical agro-ecological conditions and vegetable production of the investigated area.

There has been an increased green bean production in Hungary recently, and this cannot be done successfully without irrigation due to its high water demand and the low amount of natural rainfall in its growing areas in the vegetation period. Therefore, it is important to investigate the problems arising during green bean production under irrigation with saline waters as high-quality irrigation water is not available everywhere.

The main goal of our investigations is to determine the correlations in a soilwater-plant system in order to understand the processes taking place during secondary salinization and to find solutions for this problem to mitigate the harmful effects, mainly by means of prevention.

\section{Materials and methods}

In order to reach our research goals, a lysimeter experiment was set up, where we wanted to determine the effect of irrigation frequency, water quality, and soil conditioning on the soil and, through that, on the water supply of the indicator plant that can be manifested in the morphological parameters and the yields of the plants.

\section{The simple drainage lysimeters}

The research work was carried out in 12 simple drainage lysimeters (Fig. 1). The wall of the lysimeters is made of plastic, the depth of the soil columns in the vessels is $120 \mathrm{~cm}$, and the surface area is $0.8 \mathrm{~m}^{2}$ each.

The leachate from the lysimeters is regularly collected and quantified. The amount of precipitation is measured in the meteorological station of RIK, near the lysimeter station [3].

By means of the simple drainage lysimeters, it is easy to quantify the amount of salts leached from the soil columns as only the salt concentration of the leachate must be determined. Furthermore, exact soil sampling can be carried out from the lysimeters at different depths. 


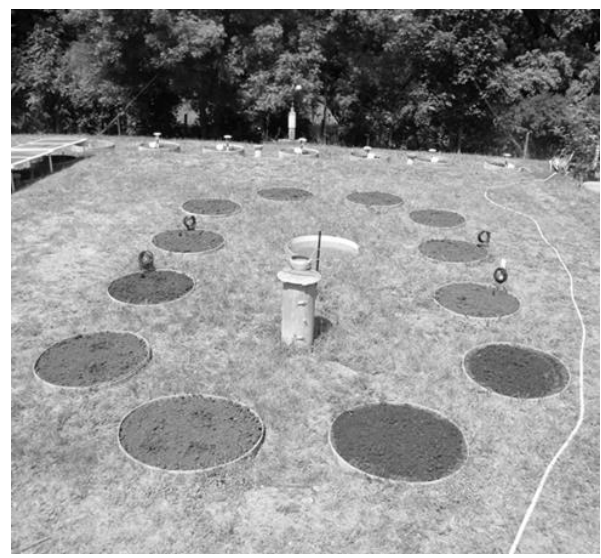

Figure 1. The simple drainage lysimeters involved in the experiment

The lysimeters were filled with Solonetz soil, whose main properties are summarized in Table 1.

Table 1. Some parameters of the soil of the lysimeters

\begin{tabular}{l|cccc}
\hline \multicolumn{1}{c}{ PARAMETER } & UNIT & LAYER & LAYER & LAYER \\
\cline { 2 - 4 } & & $0-20 \mathrm{~cm}$ & $20-40 \mathrm{~cm}$ & $40-60 \mathrm{~cm}$ \\
PH(KCL) $_{\text {TOTAL SOLUBLE }}$ & $\%$ & 0.13 & 7.23 & 7.41 \\
$\begin{array}{l}\text { SALT CONTENT } \\
\text { HUMUS CONTENT }\end{array}$ & $\%$ & 2.31 & 1.43 & 0.13 \\
NO3-N & $\mathrm{mg} / \mathrm{kg}$ & 68.6 & 14.6 & 1.07 \\
$\mathbf{P}_{2} \mathbf{O}_{5}$ & $\mathrm{mg} / \mathrm{kg}$ & 1072 & 653 & 307 \\
$\mathbf{K}_{2} \mathbf{O}$ & $\mathrm{mg} / \mathrm{kg}$ & 444 & 247 & 207 \\
\hline
\end{tabular}

\section{Treatments and indicator crop}

The effect of two treatments was studied in the experiment in a complex way: irrigation with two different qualities of water and soil conditioning. All the lysimeters were irrigated with the same weekly amount of water (15 litres per week), 6 with saline water $\left(1,600 \mathrm{mg} \mathrm{l}^{-1}\right.$ salt content), and the other 6 with deionized water. According to Zsembeli et al. [9], the quality of groundwater and 
other water sources used for irrigation (from the aquifers at $12-40 \mathrm{~m}$ depth) can be characterized by $1,600 \mathrm{mg} \mathrm{l}^{-1}$ salt content.

Taking the surface area of the lysimeters into account, 1 litre of irrigation water equals $1.25 \mathrm{~mm}$ water input. During the vegetation period of green bean, altogether $192 \mathrm{~mm}$ water was irrigated by simple sprinkling. The soil of 6 lysimeters was treated with $\mathrm{Neosol}$, and the other 6 did not get any chemical amendments. Hence, 6 replications were applied for irrigation water quality as well as for soil conditioning. The combinations of the treatments are summarized in Table 2.

Table 2. Treatments of the lysimeter experiment

\begin{tabular}{ccccc}
\hline $\begin{array}{c}\text { Lysimeter } \\
\text { no. }\end{array}$ & $\begin{array}{c}\text { Soil } \\
\text { conditioner } \\
\text { application }\end{array}$ & $\begin{array}{c}\text { Irrigation water } \\
\text { quality }\end{array}$ & $\begin{array}{c}\text { Irrigation } \\
\text { frequency }\end{array}$ & $\begin{array}{c}\text { Dosage of } \\
\text { irrigation } \\
\text { per day }\end{array}$ \\
\hline $1-3$ & Neosol (PRP) & deionized & 5 times a week & 3.01 \\
\hline $4-6$ & Neosol (PRP) & $\begin{array}{c}\text { salty well } \\
(1,600 \mathrm{mg} / \mathrm{l})\end{array}$ & 2 times a week & 7.51 \\
\hline $7-9$ & - & deionized & 5 times a week & 3.01 \\
\hline $10-12$ & - & $\begin{array}{c}\text { salty well } \\
(1,600 \mathrm{mg} / \mathrm{l})\end{array}$ & 2 times a week & 7.51 \\
\hline
\end{tabular}

The applied indicator crop was green bean (Phaseolus vulgaris L. var. nanus), the cultivar Budai piaci. The sowing date was 20/05/2018, and the final harvest (plants removed) took place on 10 July.

NPK fertilizers were added to the soil of the lysimeters in early spring: $\mathrm{N}$ (27\% substance content) $35 \mathrm{~g}, \mathrm{P}(19 \%) 67 \mathrm{~g}, \mathrm{~K}(60 \%) 23 \mathrm{~g}$ for each lysimeter.

Seedbed was created directly before sowing, and then six of the twelve lysimeters were treated with a soil conditioner (Neosol) at the dose of $50 \mathrm{~g}$ per lysimeter. According to the producer, the microbiological activity of the soil can be boosted by Neosol (distributed in pellet form) and thus also its fertility [10]. Through the application of Neosol, the soil characteristics can be improved by unblocking the nutrients in the soil [5].

Four seeds per lysimeter were sown at the depth of $4 \mathrm{~cm}$ in the arrangement illustrated in Fig. 2. 


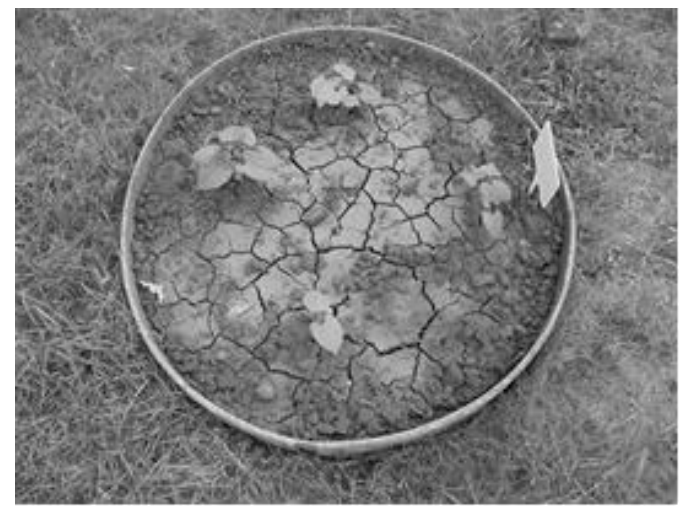

Figure 2. Arrangement of bean seedlings in a lysimeter

During the vegetation period, the pods were harvested five times; the last harvest (on $10^{\text {th }}$ July) meant the removal of the plants (including the roots).

\section{Results and discussions}

Effect of the treatments on the morphological parameters of the indicator crop

Differences due to the irrigation with saline and deionized water could be spotted even at the beginning of the growing period as the seeds irrigated with the salty well water germinated 5 days later, and this delay remained until blooming.

Table 3 contains the quantified effect of the treatments on the average height of the indicator crops.

Table 3. Effect of the complex treatments on the average plant height (Karcag, 2018)

\begin{tabular}{l|lc}
\hline \multicolumn{2}{l}{} & \multicolumn{1}{c}{ Average plant height $(\mathrm{cm})$} \\
\hline Water quality & deionized & $48.53 \pm 5.00$ \\
& saline & $43.21 \pm 4.50$ \\
Irrigation frequency & $2 \times 7.51$ & $46.13 \pm 0.06$ \\
& $5 \times 31$ & $45.62 \pm 0.57$ \\
Soil conditioning & PRP (Neosol) & $46.41 \pm 0.79$ \\
& control & $45.33 \pm 0.27$ \\
\hline
\end{tabular}


On the basis of the data, it can be established that plants irrigated with deionized water were $5.3 \mathrm{~mm}$ taller on average than plants which were treated with salty well water. The effect of the irrigation frequency was not significant; plants irrigated two times a week were minimally $(0.5 \mathrm{~cm})$ taller than those irrigated five times a week. Soil conditioning had a positive effect on plant height; treated plants were $1.1 \mathrm{~cm}$ taller than non-treated ones.

Plant height is a central part of plant ecological strategy because this morphological parameter is strongly correlated with not just life span but the time to maturity as well [4]. The canopy area, which is characteristic of the genotype too, has a major role in the photosynthetic activity of the plants and also determines transpiration capacity. In order to quantify the canopy of green bean, we weighed the total overground biomass of the indicator crops for each individual plant in the lysimeters after the final harvest (Table 4).

Table 4. Effect of the complex treatments on the overground biomass of green bean (Karcag, 2018)

\begin{tabular}{|c|c|c|}
\hline & & ound biomass (g/plant) \\
\hline \multirow[t]{2}{*}{ Water quality } & deionized & $93.47 \pm 10.91$ \\
\hline & saline & $62.50 \pm 8.27$ \\
\hline \multirow[t]{2}{*}{ Irrigation frequency } & $2 \times 7.51$ & $83.33 \pm 0.27$ \\
\hline & $5 \times 31$ & $72.64 \pm 2.36$ \\
\hline \multirow[t]{2}{*}{ Soil conditioning } & PRP (Neosol) & $85.14 \pm 1.19$ \\
\hline & control & $70.83 \pm 3.83$ \\
\hline
\end{tabular}

Comparing the average biomass values of the plants, we found that $31 \mathrm{~g}$ less weight was characteristic of the plants irrigated with salty well water. This difference cannot be considered high taking the salt sensitivity of green bean into account. The irrigation frequency resulted in a $10.7 \mathrm{~g}$ per plant higher biomass in the case of the lysimeters irrigated two times a week. The positive effect of soil conditioning was manifested in a biomass $14.3 \mathrm{~g}$ higher compared to the control plants.

It is of great importance that the biomass of green bean be as high as possible since the amount of nitrogen fixed by the plant depends not only on the genotype but on the growing ability of the plant too. The annual amount of nitrogen fixed by the plants is also important when green bean is integrated in a crop rotation. In the nodules of beans, Rhizobium phaseoli bacteria can fix the atmospheric nitrogen; therefore, green bean is considered a good forecrop.

The effect of the complex treatments was studied on the root mass too as roots highly determine the success of bean production. Only the nutrients close 
to the root system of the plants can be taken up; therefore, the underground biomass and the extension of the root system are very important factors. A larger extension of roots results in higher water uptake, and hence the root biomass has an important role not only in nutrient utilization but in drought tolerance as well. The effect of the complex treatments on the root mass is summarized in Table 5.

Table 5. Effect of the complex treatments on the root biomass of green bean (Karcag, 2018)

\begin{tabular}{l|lc}
\hline \multicolumn{2}{l}{} & \multicolumn{1}{c}{ Root biomass (g/plant) } \\
\hline Water quality & deionized & $9.55 \pm 1.54$ \\
& saline & $8.18 \pm 1.53$ \\
Irrigation frequency & $2 \times 7.51$ & $8.88 \pm 0.03$ \\
& $5 \times 31$ & $8.85 \pm 0.04$ \\
Soil conditioning & PRP (Neosol) & $9.10 \pm 0.24$ \\
& control & $8.63 \pm 0.25$ \\
\hline
\end{tabular}

On the basis of the data, it is obvious that the treatments had no significant effects on the root biomass of green bean. The only considerable difference could be observed in the case of irrigation with saline water resulting in the lowest root mass per plant, but even this stress factor did not inhibit root growth to a harmful extent. These results are in harmony with the statement that the root systems of plants are highly plastic in their development [8].

\section{Effect of the treatments on the yield of the indicator crop}

The effect of the complex treatments on the yield of green bean was partly determined by counting the number of the pods grown on each plant in the lysimeters (Fig. 3).

Regarding water quality, we counted 5.2 less pods per plant when saline well water was used for irrigation than in the lysimeters irrigated with deionized water. Irrigation frequency of two times a week with higher doses was more effective than more frequent irrigation. We could observe the positive effect of soil conditioning too, but more effective treatments were those where the irrigation with saline water was combined with favourable frequency and soil conditioning: two times a week irrigation frequency and soil conditioning resulted in 14.1 pods per plant on average, while only 9.7 pods per plant were counted for five times a week irrigation frequency with no soil conditioning. These results led to the conclusion that the application of treatment combinations 
positively influencing the moisture and salt profile of the soil, the harmful effect of secondary salinization can be mitigated regarding the number of pods of green bean.

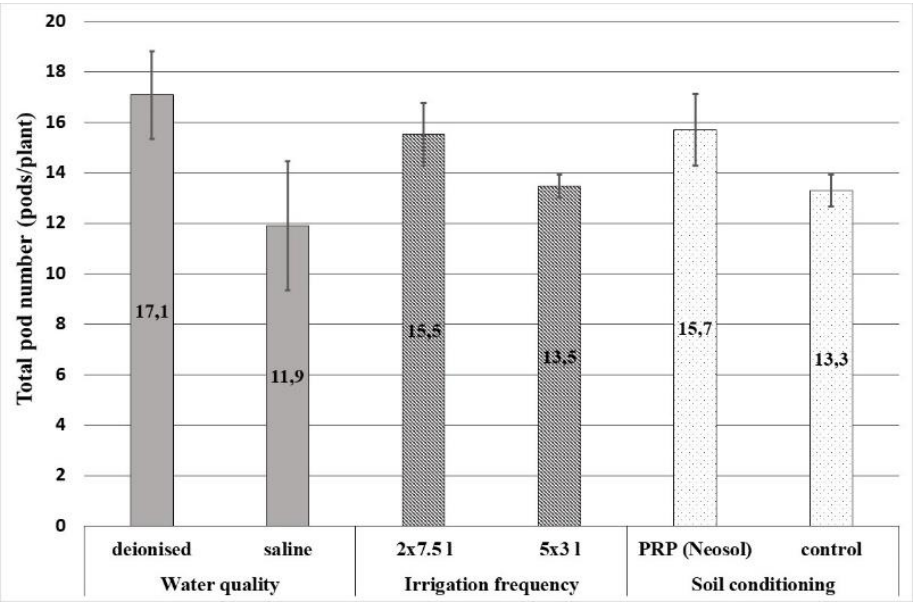

Figure 3. Effect of water quality, irrigation frequency, and soil conditioning on the total pod number of green bean (Karcag, 2018)

As the number of pods alone is not enough for the full assessment of the yield of green bean, the total weight of pods was also measured (Fig. 4).

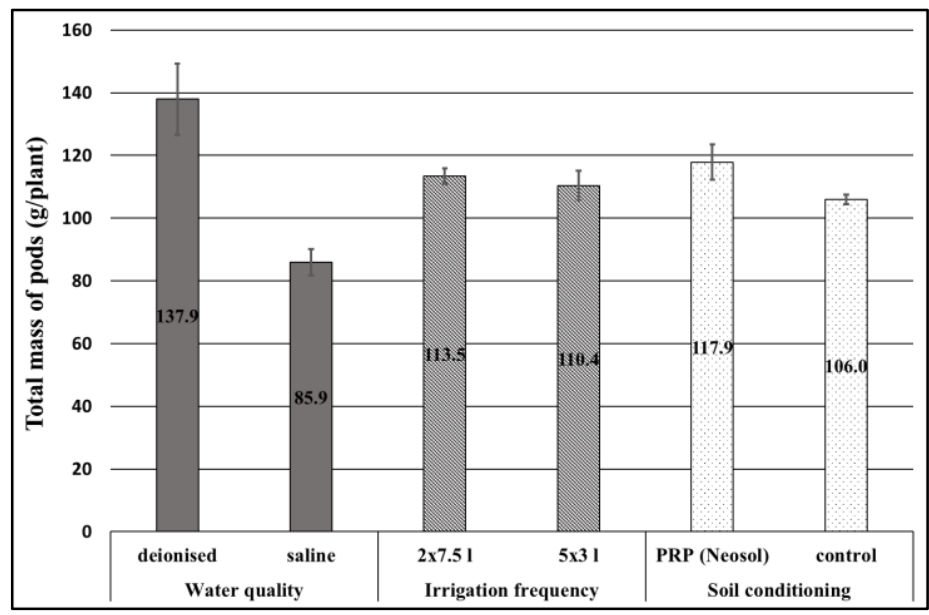

Figure 4. Effect of water quality, irrigation frequency, and soil conditioning on the total weight of pods of green bean (Karcag, 2018) 
The negative effect of the application of saline water for irrigation could be observed in the case of the yield of green bean too. The best treatment combination with saline water (two times a week irrigation frequency and soil conditioning) resulted in a $93.4 \mathrm{~g}$ per plant average pod weight, which is $14.9 \mathrm{~g}$ higher than the average pod weight in the lysimeters irrigated five times a week with saline water without soil conditioning (78.5 g per plant). Nevertheless, irrigation with saline well water decreased the potential yield, $137.9 \mathrm{~g}$ per plant pod weight could be reached by irrigation with deionized water. We established that the yield-declining effect of secondary salinization can be mitigated by the application of soil conditioner and proper irrigation frequency.

\section{Conclusions}

On the basis of our results, it can be established that in the case of irrigation with saline water the amount of water must be limited to the demand of the crop; over-irrigation increases the risk of secondary salinization. The mitigation of this unfavourable process is possible by proper irrigation frequency and soil conditioning taking the given soil conditions (texture, infiltration rate, etc.) into consideration.

The treatments having positive effect on the physical and hydrological (hence on the chemical) soil status (lower irrigation frequency with soil conditioning) resulted in higher yields and better morphological properties of the green bean.

In areas with unfavourable agro-ecological conditions, soil conditioning combined with the optimization of irrigation (control of quantity, frequency) is highly recommended as the safety of crop production can be increased in a soilprotective way.

\section{Acknowledgements}

The research was financed by the Higher Education Institutional Excellence Programme (20428-3/2018/FEKUTSTRAT) of the Ministry of Human Capacities in Hungary, within the framework of the 4. thematic programme of the University of Debrecen. 


\section{References}

[1] Adams, R. M., Hurd, B. H., Lenhart, S., Leary, N. (1998), Effects of global climate change on agriculture: An interpretative review. Climate Research 11(1), 19-30.

[2] Howden, S. M., Soussana, J. F., Tubiello, F. N., Chhetri, N., Dunlop, M., Meinke, H. (2007), Adapting agriculture to climate change. Proceedings of the National Academy of Sciences 104(50), 19691-19696.

[3] Szűcs L., Tuba G., Czimbalmos R., Zsembeli J. (2015), A PRP-SOL talajkondicionáló szer hatása a talaj hidraulikus tulajdonságaira hagyományos és redukált talajmüvelési rendszerekben. In: Madarász, B. (ed.), Környezetkímélö talajmüvelési rendszerek Magyarországon. Budapest: MTA-CSFK-FTI. 111-121.

[4] Moles, A. T., Warton, D. I., Warman, L., Swenson, N. G., Laffan, S. W., Zanne, A. E., Leishman, M. R. (2009), Global patterns in plant height. Journal of Ecology 97(5), 923-932.

[5] Sulewska, H., Koziara, W., Szymańska, G., Niewiadomska, A., Panasiewicz, K., Ratajczak, K. (2016), Response of spring barley to PRP SOL application as a complex of mineral inducer process (MIP). Nauka Przyroda Technologie 10(2), 17.

[6] Szabolcs I., Darab K., Várallyay GY. (1969a), A tiszai öntözőrendszerek és a Magyar Alföld talajainak termékenysége. II. A talajvíz „kritikus” mélysége a kiskörei öntözörendszer által érintett területen. Agrokémia és Talajtan 18, 211-220.

[7] Szabolcs I., Darab K., Várallyay, Gy. (1969b), A tiszai öntözőrendszerek és a Magyar Alföld talajainak termékenysége III. Az öntözés lehetőségeit és feltételei ábrázoló 1:25000 léptékü térképek készítésének módszerei. Agrokémia és Talajtan 18, 221-234.

[8] Williamson, L. C., Ribrioux, S. P., Fitter, A. H., Leyser, H. O. (2001), Phosphate availability regulates root system architecture in Arabidopsis. Plant Physiology 126(2), 875-882.

[9] Zsembeli, J., Szücs, L., Blaskó, L. (2011), Secondary salinization by irrigation from drilled wells in [the] Karcag area. Növénytermelés 183(3), 305-308.

[10] http://www.prp-technologies.eu/en/products-and-services/our-products/neosol $(12 / 03 / 2019)$. 